\title{
Sample size for morphological traits of pigeonpea
}

\section{Tamanho de amostra para caracteres morfológicos de feijão guandu}

\author{
Giovani Facco ${ }^{1}$; Alberto Cargnelutti Filho ${ }^{2 *}$; Alessandro Dal'Col Lúcio ${ }^{2}$; \\ Gustavo Oliveira dos Santos ${ }^{3}$; Réges Bellé Stefanello ${ }^{4}$; Bruna Mendonça Alves ${ }^{1}$; \\ Cláudia Burin ${ }^{5}$; Ismael Mario Márcio Neu ${ }^{4}$ Jéssica Andiara Kleinpaul ${ }^{4}$
}

\begin{abstract}
The objectives of this study were to determine the sample size (i.e., number of plants) required to accurately estimate the average of morphological traits of pigeonpea (Cajanus cajan L.) and to check for variability in sample size between evaluation periods and seasons. Two uniformity trials (i.e., experiments without treatment) were conducted for two growing seasons. In the first season (2011/2012), the seeds were sown by broadcast seeding, and in the second season (2012/2013), the seeds were sown in rows spaced $0.50 \mathrm{~m}$ apart. The ground area in each experiment was $1,848 \mathrm{~m}^{2}$, and 360 plants were marked in the central area, in a $2 \mathrm{~m} \times 2 \mathrm{~m}$ grid. Three morphological traits (e.g., number of nodes, plant height and stem diameter) were evaluated 13 times during the first season and 22 times in the second season. Measurements for all three morphological traits were normally distributed and confirmed through the Kolmogorov-Smirnov test. Randomness was confirmed using the Run Test, and the descriptive statistics were calculated. For each trait, the sample size (n) was calculated for the semiamplitudes of the confidence interval (i.e., estimation error) equal to $2,4,6, \ldots, 20 \%$ of the estimated mean with a confidence coefficient $(1-\alpha)$ of $95 \%$. Subsequently, $n$ was fixed at 360 plants, and the estimation error of the estimated percentage of the average for each trait was calculated. Variability of the sample size for the pigeonpea culture was observed between the morphological traits evaluated, among the evaluation periods and between seasons. Therefore, to assess with an accuracy of $6 \%$ of the estimated average, at least 136 plants must be evaluated throughout the pigeonpea crop cycle to determine the sample size for the traits (e.g., number of nodes, plant height and stem diameter) in the different evaluation periods and between seasons.
\end{abstract}

Key words: Cajanus cajan L., sample dimensioning, experimental precision

\section{Resumo}

Os objetivos deste estudo foram determinar o tamanho de amostra (número de plantas) para estimação da média de caracteres morfológicos de feijão guandu (Cajanus cajan L.) e verificar se há variabilidade do tamanho de amostra entre as épocas de avaliação e entre os anos agrícolas. Foram conduzidos dois

\footnotetext{
${ }^{1}$ Eng $^{\text {os }}$ Agros $^{\text {, }}$ Discentes de Doutorado do Programa de Pós-Graduação em Agronomia, Universidade Federal de Santa Maria, UFSM, Santa Maria, RS, Brasil. E-mail: giovanifacco2011@gmail.com; brunamalves11@gmail.com

2 Profs. Drs., Dept ${ }^{\circ}$ de Fitotecnia, Centro de Ciências Rurais, UFSM, Santa Maria, RS, Brasil. E-mail: alberto.cargnelutti.filho@, gmail.com; adlucio.capi@gmail.com

${ }^{3}$ Eng $^{\circ}$ Agr $^{\circ}$, Discentes de Doutorado do Programa de Pós-Graduação em Engenharia Agrícola, UFSM, Santa Maria, RS, Brasil. E-mail: gustavo_santos_rs@hotmail.com

${ }^{4}$ Discentes de Graduação em Agronomia, UFSM, Santa Maria, RS, Brasil. E-mail: regesstefanello@hotmail.com; ismaelmmneu@ hotmail.com; kleinpauljessica@gmail.com

5 Eng ${ }^{\text {a }}$ Florestal, Discentes de Doutorado do Programa de Pós-Graduação em Engenharia Florestal, UFSM, Santa Maria, RS, Brasil. E-mail: clauburin@gmail.com

* Autor para correspondência
} 
ensaios de uniformidade (experimentos sem tratamentos), em dois anos agrícolas. No primeiro ano agrícola (2011/2012), a semeadura foi realizada a lanço e no segundo ano agrícola (2012/2013), a semeadura foi realizada em linhas espaçadas a $0,50 \mathrm{~m}$. A área útil, em cada um dos experimentos foi de $1.848 \mathrm{~m}^{2}$, e foram demarcadas 360 plantas, na área central, em um gride de $2 \mathrm{~m} \times 2 \mathrm{~m}$. Foram avaliados três caracteres morfológicos (número de nós, altura de planta e diâmetro de caule) em 13 épocas no primeiro ano agrícola e em 22 épocas no segundo ano agrícola. Em todos os caracteres foi verificada a normalidade, por meio do teste de Kolmogorov-Smirnov e a aleatoriedade pelo Run Test e calculadas as estatísticas descritivas. Para cada caractere, foi calculado o tamanho de amostra (n), para as semiamplitudes do intervalo de confiança (erros de estimação) iguais a 2, 4, 6, .., 20\% da estimativa da média, com coeficiente de confiança (1- $\alpha$ ) de 95\%. Posteriormente, fixou-se n em 360 plantas e foi calculado o erro de estimação em percentagem da estimativa da média para cada um dos caracteres. Há variabilidade do tamanho de amostra para a cultura de feijão guandu entre os caracteres morfológicos avaliados, entre as épocas de avaliação e entre os anos agrícolas. Sendo que para avaliar com uma precisão de 6\% da estimativa da média, 136 plantas avaliadas ao longo do ciclo da cultura de feijão guandu são necessárias para determinar o tamanho de amostra para os caracteres, número de nós, altura de planta e diâmetro de caule nas diferentes épocas de avaliação e entre os anos agrícolas.

Palavras-chave: Cajanus cajan L., dimensionamento amostral, precisão experimental

\section{Introduction}

Pigeonpea (Cajanus cajan L.) belongs to the family Fabaceae and is generally considered to be a self-pollinating plant with a low rate of crosspollination(WUTKE, 1986). The genus most closely related to Cajanus is Alylosia. Pigeonpea occurs in semi-arid areas due to certain morphological traits, such as its aggressive root system. One of its main uses is in animal feed, primarily in the form of either, hay, silage, and chopped greens; as dry grounds in the form of bran; through grazing; or as a protein bank or intercropped with grasses (NENE; SHEILA, 1990; VAN DER MAESEN, 1990).

To properly evaluate pigeonpea plants it is necessary to calculate the ideal sample size, so that the number of plants evaluated is representative of all plants in the population and expresses the lowest possible error regarding the traits inherent to the population. In crop research, it is common to measure several traits in many individual plants. The evaluation of these traits in all individuals is limited by labor, time, precision of the assessments being made and a comprehensive routine (BUSSAB; MORETTIN, 2011). Thus, the evaluation of a sample plants is used to obtain estimates that are representative of the population and to minimize the factors limiting the evaluation of the entire plant population (STEEL et al., 1997). The determination of sample size depends mainly on the homogeneity of the sample observations and on the desired level of precision (CAMPOS, 1985).

The ideal sample size has been determined to estimate the mean of morphological traits in crops, such as soybean (CARGNELUTTI FILHO et al., 2009), castor bean (CARGNELUTTI FILHO et al., 2010), other bean crops (CARGNELUTTI FILHO et al., 2008) and turnip (CARGNELUTTI FILHO et al., 2014). However, similar studies for pigeonpea have not been conducted.

The objectives of this study were to determine the sample size (i.e., number of plants) to estimate the average of morphological traits in pigeonpea and to determine variability in the sample size between the evaluation periods and seasons.

\section{Material and Methods}

Two uniformity trials (also called blank experiments or experiments without treatment) were conducted using the pigeonpea, cultivar BRS Mandarin. This pigeonpea variety may have a yearly, or, more commonly, semi-perennial cycle, usually growing up to $1-2 \mathrm{~m}$ or even up to $4 \mathrm{~m}$ tall in multiannual management systems. In 
the uniformity trials, all procedures (e.g., seeding, fertilization, cultivation, harvesting and evaluations) were conducted in identical fashion throughout the experimental area. The first uniformity trial was conducted during the 2011/2012 season, and the second uniformity trial during the 2012/2013 season. Both trials were conducted in the experimental area of the Department of Plant Science at the Federal University of Santa Maria, Rio Grande do Sul $\left(29^{\circ} 42^{\prime} \mathrm{S}, 53^{\circ} 49^{\prime} \mathrm{W}\right.$, and $95 \mathrm{~m}$ altitude $)$. The climate here is characterized as humid subtropical ( $\mathrm{CFa}$ type), according to the Köppen classification. The soil is a transition between the São Pedro Mapping Unit (red dystrophic sandy acrisol) and the Santa Maria Mapping Unit (typical argillic, hypochromic alisol) (STRECK et al., 2008).

Pigeonpea seeds were sown during the first season (2011/2012) by broadcast seeding at a density of 20 seeds $\mathrm{m}^{-2}$, in an area of $28 \mathrm{~m} \times 66 \mathrm{~m}$ $\left(1,848 \mathrm{~m}^{2}\right)$ on $01 / 26 / 2012$. The plants were fertilized at $800 \mathrm{~kg} \mathrm{ha}^{-1}$ with NPK fertilizer (05-20-20). Emergence of the plants took place on 01/31/2012. Wooden stakes were used to form a grid of $2 \mathrm{~m} \times$ $2 \mathrm{~m}$, consisting of 30 rows and 12 columns, with the stakes spaced at $2 \mathrm{~m}$ in the rows and columns. A single plant closest to each wooden stake was marked, totaling 360 labeled plants. At 42 days after sowing (DAS) the first morphological traits were evaluated. The number of nodes on the main stem was counted and plant height was measured using a ruler. Stem diameter was measured using an analog caliper (in $\mathrm{mm}$ ) on the main stem, $5 \mathrm{~cm}$ from the ground. During the first season, 13 evaluations were conducted during the crop cycle, the last of which was performed at 125 DAS when the plants were flowering.

Pigeonpea seeds were sown during the second season (2012/2013) in rows, at $0.50 \mathrm{~m}$ spacing, at a density of 20 seeds $\mathrm{m}^{-2}$, and an area of $28 \mathrm{~m} \times 66 \mathrm{~m}$ $\left(1,848 \mathrm{~m}^{2}\right)$ on $11 / 20 / 2012$. The plants were fertilized at $800 \mathrm{~kg} \mathrm{ha}^{-1}$ with NPK (05-20-20). Morphological trait evaluations during the second season started at 16 DAS and the last one was conducted at 162 DAS when the plants were flowering. The same traits were evaluated and the same methods were used as during the first season. During both seasons, the minimum and maximum daily air temperatures $\left({ }^{\circ} \mathrm{C}\right)$ and precipitation $(\mathrm{mm})$, was collected at the automatic experimental station of the Federal University of Santa Maria, located $30 \mathrm{~m}$ away from the experimental site. The mean daily temperature was calculated (Figures 1 and 2).

Figure 1. Minimum, maximum and mean daily air temperatures $\left({ }^{\circ} \mathrm{C}\right)$ and precipitation $(\mathrm{mm})$, corresponding to the first season (2011/2012) of experiment with pigeonpea (Cajanus cajan L.).

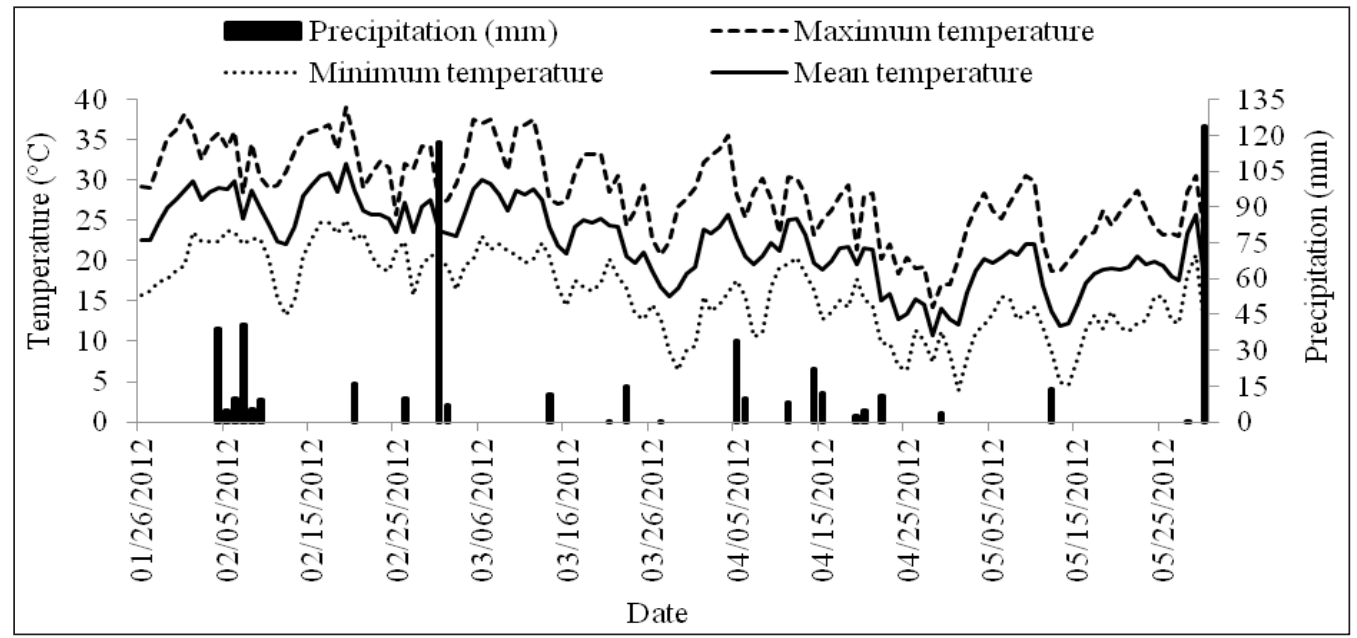

Data from automatic experimental station of the Federal University of Santa Maria (Source: INMET Network Data). 
Figure 2. Minimum, maximum and mean daily air temperatures $\left({ }^{\circ} \mathrm{C}\right)$ and precipitation $(\mathrm{mm})$, corresponding to the second season (2012/2013) of experiment with pigeonpea (Cajanus cajan L.).

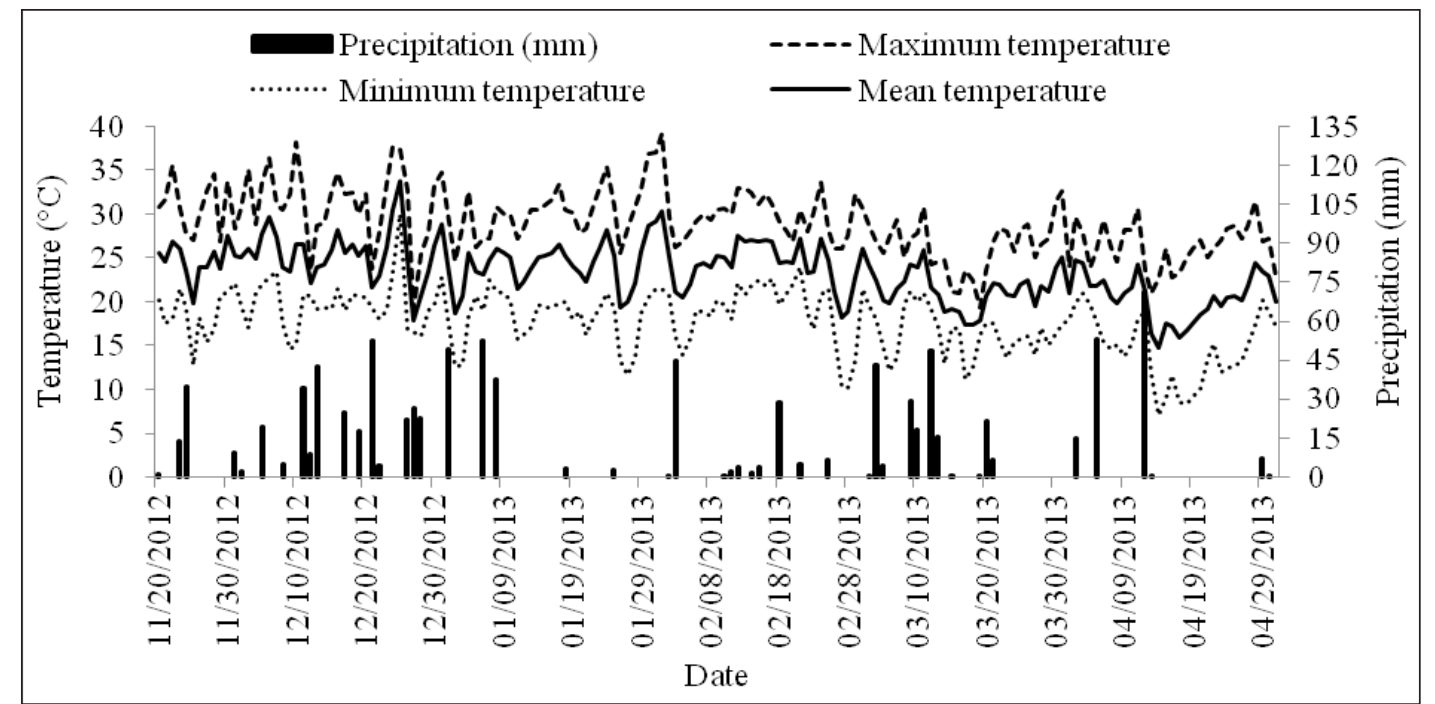

Data from automatic experimental station of the Federal University of Santa Maria (Source: INMET Network Data).

For all the morphological traits evaluated, normality and randomness/independence of the data were verified by Kolmogorov-Smirnov and the Run Test (CAMPOS, 1983), respectively. The experiment consisted of 30 rows and 12 columns, and the Run Test was carried out starting at row 1 , column 1 ; proceeding to row 1 , column 12; and returning to row 2 , column 12 ; proceeding to row 2 , column 1 ; and restarting at row 3 , column 1 ; proceeding to row 3 , column 12 ; and so on, until the test concluded at row 30 , column 1 .

For each morphological trait, the minimum, maximum, mean, median, standard deviation, standard error of the mean, coefficient of variation, skewness and kurtosis were determined. The sample size (n) was calculated for the semiamplitudes of the confidence interval (i.e., estimation errors) equal to $2,4,6, \ldots, 20 \%$ of the mean estimate (i.e., error $\times$ mean), with a confidence coefficient (i.e., 1- $\alpha$ ) of $95 \%$, based on the equation $\mathrm{n}=\frac{\mathrm{t}_{\alpha / 2} \mathrm{~s}^{2}}{(\text { estimation error })^{2}}$ (BARBETTA et al., 2004; SPIEGEL et al., 2004; BUSSAB; MORETTIN, 2011), where $t_{\alpha / 2}$ is the critical value of Student's $t$ distribution in which the right area is equal to $\alpha / 2$ [i.e., the value of $t$ wherein $\mathrm{P}\left(\mathrm{t}>\mathrm{t}_{\alpha / 2}\right)=\alpha / 2$ with $(\mathrm{n}-1)$ degrees of freedom at $\alpha=$
$5 \%$ error probability], and $\mathrm{s}^{2}$ is the variance.

By using the sample size equation, $\mathrm{n}$ was fixed at 360 plants, and the estimation error was calculated as a percentage of the mean estimate (m) for each of the traits based on the equation estimation error $=100 \frac{t_{\alpha / 2} s}{\sqrt{n} m}$, where $s$ is the estimated standard deviation. Statistical analyses were carried out by using Excel ${ }^{\circledR}$ (Microsoft Office).

\section{Results and Discussion}

The number of nodes in the plants marked during the first season ranged from 4 to 68 nodes per plant on the main stem and the variance ranged from 6.85 to 45.50. During the second season, the number of nodes per plant displayed further extreme variation, ranging from a minimum of 1 to a maximum of 84 nodes per plant on the main stem, with variance ranging from 0.27 to 58.75 . The mean number of nodes per plant in the first season ranged from 13.21 to 48.87 , while in the second season the mean ranged from 1.47 to 61.78 nodes per plant. The mean and median numbers of nodes per plant were similar in both seasons (Table 1). 
Table 1. Minimum (min), maximum (max), mean, median, standard deviation (SD), standard error of the mean (SE), coefficient of variation (CV), variance (VAR), skewness (SK), and kurtosis (K), p-value the normality KolmogorovSmirnov test (KS) and p-value the randomness the Run Test, the number of nodes per plant, in 360 plants of pigeonpea (Cajanus cajan L.), evaluated in the seasons 2011/2012 and 2012/2013.

\begin{tabular}{|c|c|c|c|c|c|c|c|c|c|c|c|c|}
\hline $\mathrm{DAS}^{(1)}$ & $\min$ & $\max$ & mean & median & SD & $\mathrm{SE}$ & CV (\%) & VAR & SK & $\mathrm{K}+3$ & $\mathrm{KS}^{(2)}$ & $\operatorname{Run}^{(3)}$ \\
\hline \multicolumn{13}{|c|}{ Season 2011/2012 } \\
\hline 42 & 4 & 22 & 13.21 & 13.00 & 3.12 & 0.16 & 23.63 & 9.74 & 0.18 & 2.96 & $2.03^{*}$ & 0.00 \\
\hline 48 & 9 & 23 & 16.00 & 16.00 & 2.62 & 0.14 & 16.36 & 6.85 & 0.06 & 2.81 & $1.78^{*}$ & 0.41 \\
\hline 55 & 12 & 31 & 20.64 & 20.00 & 3.56 & 0.19 & 17.22 & 12.64 & 0.22 & 2.46 & $1.79 *$ & 0.00 \\
\hline 62 & 15 & 36 & 24.85 & 25.00 & 4.11 & 0.22 & 16.56 & 16.93 & 0.12 & 2.61 & $1.23 \mathrm{~ns}$ & 0.16 \\
\hline 69 & 15 & 44 & 27.99 & 28.00 & 4.39 & 0.23 & 15.67 & 19.25 & 0.07 & 3.16 & $1.10 \mathrm{~ns}$ & 0.05 \\
\hline 76 & 16 & 44 & 30.48 & 30.00 & 4.53 & 0.24 & 14.86 & 20.50 & -0.12 & 3.00 & $1.16 \mathrm{~ns}$ & 0.01 \\
\hline 83 & 16 & 48 & 33.24 & 33.00 & 4.89 & 0.26 & 14.71 & 23.92 & -0.23 & 3.19 & $1.18 \mathrm{~ns}$ & 0.02 \\
\hline 90 & 22 & 52 & 36.05 & 36.00 & 5.11 & 0.27 & 14.17 & 26.11 & -0.15 & 3.11 & $1.08 \mathrm{~ns}$ & 0.18 \\
\hline 98 & 22 & 56 & 37.18 & 37.00 & 5.10 & 0.27 & 13.72 & 26.04 & -0.05 & 3.35 & $1.07 \mathrm{~ns}$ & 0.22 \\
\hline 104 & 24 & 58 & 39.98 & 40.00 & 5.60 & 0.30 & 14.02 & 31.41 & -0.10 & 3.16 & $1.24 \mathrm{~ns}$ & 0.11 \\
\hline 111 & 24 & 59 & 41.76 & 42.00 & 5.76 & 0.30 & 13.80 & 33.21 & -0.17 & 3.23 & $1.21 \mathrm{~ns}$ & 0.07 \\
\hline 119 & 26 & 62 & 45.65 & 46.00 & 6.36 & 0.34 & 13.94 & 40.46 & -0.21 & 3.06 & $0.91 \mathrm{~ns}$ & 0.00 \\
\hline 125 & 28 & 68 & 48.87 & 49.00 & 6.75 & 0.36 & 13.80 & 45.50 & -0.30 & 3.31 & $1.34 \mathrm{~ns}$ & 0.41 \\
\hline \multicolumn{13}{|c|}{ Season $2012 / 2013$} \\
\hline 16 & 1 & 4 & 1.47 & 1.00 & 0.52 & 0.03 & 35.49 & 0.27 & 0.48 & 2.61 & $6.73^{*}$ & 0.00 \\
\hline 23 & 2 & 9 & 3.45 & 3.00 & 0.67 & 0.04 & 19.42 & 0.45 & 1.53 & 15.06 & $5.57^{*}$ & 0.51 \\
\hline 30 & 3 & 11 & 5.72 & 6.00 & 1.09 & 0.06 & 19.11 & 1.19 & 0.18 & 3.64 & $3.34^{*}$ & 0.00 \\
\hline 37 & 5 & 13 & 9.18 & 9.00 & 1.64 & 0.09 & 17.88 & 2.69 & -0.14 & 2.39 & $2.75^{*}$ & 0.00 \\
\hline 44 & 5 & 17 & 11.37 & 12.00 & 2.29 & 0.12 & 20.14 & 5.24 & -0.21 & 2.30 & $2.42 *$ & 0.00 \\
\hline 51 & 6 & 20 & 14.11 & 15.00 & 2.91 & 0.15 & 20.61 & 8.46 & -0.37 & 2.31 & $2.74^{*}$ & 0.00 \\
\hline 58 & 7 & 25 & 16.65 & 17.00 & 3.64 & 0.19 & 21.88 & 13.27 & -0.34 & 2.48 & $2.20^{*}$ & 0.00 \\
\hline 65 & 8 & 29 & 19.71 & 20.00 & 4.42 & 0.23 & 22.41 & 19.51 & -0.33 & 2.29 & $2.07^{*}$ & 0.00 \\
\hline 72 & 11 & 33 & 22.44 & 23.00 & 4.92 & 0.26 & 21.93 & 24.22 & -0.23 & 2.22 & $1.50^{*}$ & 0.00 \\
\hline 79 & 14 & 39 & 26.92 & 28.00 & 5.51 & 0.29 & 20.47 & 30.38 & -0.26 & 2.28 & $1.62 *$ & 0.00 \\
\hline 86 & 15 & 46 & 31.00 & 31.00 & 5.94 & 0.31 & 19.15 & 35.25 & -0.35 & 2.65 & $1.52 *$ & 0.00 \\
\hline 93 & 17 & 48 & 35.38 & 36.00 & 6.54 & 0.34 & 18.49 & 42.82 & -0.44 & 2.62 & $1.42 *$ & 0.00 \\
\hline 100 & 17 & 53 & 38.59 & 39.00 & 6.78 & 0.36 & 17.58 & 46.02 & -0.53 & 2.81 & $1.69 *$ & 0.00 \\
\hline 107 & 20 & 55 & 41.21 & 41.50 & 6.96 & 0.37 & 16.89 & 48.43 & -0.39 & 2.67 & $1.29 \mathrm{~ns}$ & 0.00 \\
\hline 114 & 20 & 64 & 45.79 & 47.00 & 7.36 & 0.39 & 16.07 & 54.15 & -0.37 & 2.78 & $1.28 \mathrm{~ns}$ & 0.00 \\
\hline 120 & 23 & 64 & 48.44 & 49.00 & 7.16 & 0.38 & 14.79 & 51.31 & -0.41 & 2.91 & $1.19 \mathrm{~ns}$ & 0.00 \\
\hline 128 & 23 & 67 & 50.31 & 51.00 & 7.26 & 0.38 & 14.42 & 52.65 & -0.38 & 2.97 & $0.93 \mathrm{~ns}$ & 0.00 \\
\hline 135 & 23 & 69 & 53.29 & 54.00 & 7.53 & 0.40 & 14.12 & 56.65 & -0.45 & 3.19 & $1.22 \mathrm{~ns}$ & 0.00 \\
\hline 141 & 32 & 73 & 55.83 & 56.00 & 7.54 & 0.40 & 13.50 & 56.80 & -0.39 & 2.93 & $1.57^{*}$ & 0.04 \\
\hline 148 & 33 & 77 & 57.24 & 58.00 & 7.54 & 0.40 & 13.17 & 56.87 & -0.36 & 2.94 & $1.43^{*}$ & 0.21 \\
\hline 156 & 33 & 79 & 59.07 & 60.00 & 7.66 & 0.40 & 12.98 & 58.75 & -0.38 & 2.95 & $1.09 \mathrm{~ns}$ & 0.11 \\
\hline 162 & 38 & 84 & 61.78 & 62.00 & 7.61 & 0.40 & 12.31 & 57.85 & -0.25 & 2.68 & $1.21 \mathrm{~ns}$ & 0.33 \\
\hline
\end{tabular}

(1) Days after sowing. ${ }^{(2)} *$ Significant at $5 \%$ level of probability (not normally distributed). ${ }^{\text {ns }}$ Not significant (normally distributed). ${ }^{(3)} \mathrm{p}$-value $\leq 0.05$, significant at $5 \%$ level of probability (series of not randomized data). 
In general, asymmetry values close to 0 and kurtosis values close to 3 suggested that the data was normally distributed, which was proven through the Kolmogorov-Smirnov test (Table 1). Although the data was not normally distributed in $51 \%$ of cases (18 out of 35 cases), it can be considered as being close to normally distributed due the large number of plants evaluated (FONSECA; MARTINS, 1995; BUSSAB; MORENTTIN, 2011). Therefore, in relation to normality, our sample size study data provides reliable data based on the Student's $t$ distribution. Thirty-two per cent of the cases (11 of 35 cases) showed a random distribution.

The coefficient of variation $(\mathrm{CV})$ values during the first season for the number of nodes per plant ranged from $13.80 \%$ at the end of the cultivation cycle to $23.63 \%$ at the beginning of the cultivation cycle. The second season's CV values were similar, but more variable than the first season, ranging from 12.31 to $35.49 \%$, with higher values observed at the beginning of the cycle. These results suggest that in the initial stage of cultivation in both seasons, a larger sample size was necessary to estimate the average number of nodes per plant. The $\mathrm{CV}$ values were similar to those found for other morphological traits, such as plant height, stem diameter and the number of stems per plant of pigeonpea in different population arrangements (MAIOR JÚNIOR et al., 2009).

Plant height measurements during the first season ranged between 21 and $241 \mathrm{~cm}$, and the variance ranged from 178.18 to $495.04 \mathrm{~cm}^{2}$ (Table 2 ). These values were similar to those observed in turnip (CARGNELUTTI FILHO et al., 2014). Plant height measurements during the second season fluctuated from a minimum of 2 to a maximum of $327 \mathrm{~cm}$, and the variance ranged from 3.19 to $1,731.10 \mathrm{~cm}^{2}$. The average plant height during the first season ranged from 50.41 to $192.02 \mathrm{~cm}$, and the average during the second season was between 5.75 and $253.48 \mathrm{~cm}$ (Table 2). Similar plant height values have been reported for dwarf pigeonpea (FARIAS et al., 2013).
In general, the plant height measurements followed a trend throughout the growing cycle, which was similar to the trend noted for the number of nodes. Asymmetry values close to 0 and kurtosis values close to 3 suggest that the data is normally distributed, which can be observed using the Kolmogorov-Smirnov test (Table 2). However, $40 \%$ of cases (14 out of 35 ), did not show a normal distribution. In the second season, no cases fit the normal distribution.

The plant height $\mathrm{CV}$ values for the first season ranged from $11.49 \%$ at the end of the cycle, to $26.48 \%$ at the beginning of the cycle. During the second season, the data were similar to the first, but with higher values ranging from $16.41 \%$ to $31.04 \%$, where the largest variability was at the beginning of the crop cycle. The plant height $\mathrm{CV}$ values were similar to those of plant height at maturity, and the number of nodes per plant in a soybean culture (CARGNELUTTI FILHO et al., 2009) and were similar to those for the plant height of crambe (CARGNELUTTI FILHO et al., 2011). These results suggest that at the beginning of the cycle, in both years, a larger sample size is required to estimate mean plant height, and in the second season, a larger sample size should be permitted in comparison to the first season.

Stem diameter values during the first season ranged from 5 and $30 \mathrm{~mm}$, and the variance ranged from 3.54 to $16.18 \mathrm{~mm}^{2}$, continually increasing during the season (Table 3). Stem diameter values during the second season ranged from 2 to $34 \mathrm{~mm}$, and the variance ranged from 0.90 to $22.69 \mathrm{~mm}^{2}$. The mean values of stem diameter during the first season ranged from 8.73 to $17.84 \mathrm{~mm}$, and during the second season, the mean was between 3.84 and 17.13 $\mathrm{mm}$. The mean stem diameter values of both seasons were similar, tending to stabilize at the end of each season with a stem diameter close to $17 \mathrm{~mm}$ (Table 3 ). The mean and median stem diameter values were very similar and normally distributed. Maior Júnior et al. (2009) obtained higher stem diameter values in pigeonpea than in the current study. 
Table 2. Minimum ( $\min$ ), maximum (max), mean, median, standard deviation (SD), standard error of the mean (SE), coefficient of variation (CV), variance (VAR), skewness (SK), and kurtosis (K), p-value the normality KolmogorovSmirnov test (KS) and p-value the randomness the Run Test, the plant height in $\mathrm{cm}$, in 360 plants of pigeonpea (Cajanus cajan L.), evaluated in the seasons 2011/2012 and 2012/2013.

\begin{tabular}{|c|c|c|c|c|c|c|c|c|c|c|c|c|}
\hline $\mathrm{DAS}^{(1)}$ & $\min$ & $\max$ & mean & median & $\mathrm{SD}$ & SE & CV (\%) & VAR & SK & $\mathrm{K}+3$ & $\mathrm{KS}^{(2)}$ & $\operatorname{Run}^{(3)}$ \\
\hline \multicolumn{13}{|c|}{ Season 2011/2012 } \\
\hline 42 & 21 & 85 & 50.41 & 50.05 & 13.35 & 0.70 & 26.48 & 178.18 & 0.27 & 2.50 & $1.08 \mathrm{~ns}$ & 0.00 \\
\hline 48 & 34 & 111 & 69.17 & 69.05 & 14.72 & 0.78 & 21.28 & 216.74 & 0.04 & 2.56 & $0.69 \mathrm{~ns}$ & 0.25 \\
\hline 55 & 47 & 132 & 88.98 & 87.85 & 16.29 & 0.86 & 18.30 & 265.22 & -0.01 & 2.54 & $0.69 \mathrm{~ns}$ & 0.17 \\
\hline 62 & 56 & 155 & 101.98 & 101.15 & 17.26 & 0.91 & 16.93 & 297.98 & -0.06 & 2.58 & $0.89 \mathrm{~ns}$ & 0.07 \\
\hline 69 & 70 & 160 & 115.72 & 115.50 & 17.47 & 0.92 & 15.09 & 305.05 & -0.16 & 2.59 & $1.13 \mathrm{~ns}$ & 0.07 \\
\hline 76 & 75 & 175 & 128.28 & 127.70 & 18.46 & 0.97 & 14.39 & 340.68 & -0.11 & 2.64 & $0.81 \mathrm{~ns}$ & 0.00 \\
\hline 83 & 87 & 185 & 139.30 & 140.55 & 18.36 & 0.97 & 13.18 & 337.26 & -0.17 & 2.81 & $0.63 \mathrm{~ns}$ & .04 \\
\hline 90 & 95 & 197 & 148.07 & 148.55 & 19.23 & 1.01 & 12.98 & 369.65 & -0.15 & 2.75 & $0.55 \mathrm{~ns}$ & 0.34 \\
\hline 98 & 101 & 199 & 152.97 & 153.00 & 19.09 & 1.01 & 12.48 & 364.47 & -0.20 & 2.77 & $0.52 \mathrm{~ns}$ & 0.25 \\
\hline 104 & 103 & 210 & 164.13 & 165.50 & 20.21 & 1.07 & 12.31 & 408.49 & -0.31 & 2.88 & $0.73 \mathrm{~ns}$ & 0.46 \\
\hline 111 & 108 & 218 & 171.49 & 172.80 & 21.02 & 1.11 & 12.26 & 441.77 & -0.38 & 2.97 & $0.73 \mathrm{~ns}$ & 0.46 \\
\hline 119 & 112 & 229 & 182.39 & 184.45 & 21.43 & 1.13 & 11.75 & 459.21 & -0.59 & 3.25 & $1.02 \mathrm{~ns}$ & 92 \\
\hline 125 & 118 & 241 & 192.02 & 192.75 & 22.25 & 1.17 & 11.59 & 495.04 & -0.53 & 3.20 & $0.86 \mathrm{~ns}$ & 0.46 \\
\hline \multicolumn{13}{|c|}{ Season $2012 / 2013$} \\
\hline 16 & 2 & 11 & 5.75 & 5.80 & 1.79 & 0.09 & 31.04 & 3.19 & 0.04 & 2.40 & $1.00 \mathrm{~ns}$ & 0.00 \\
\hline 23 & 3 & 19 & 11.33 & 11.20 & 2.91 & 0.15 & 25.74 & 8.50 & -0.06 & 2.55 & $1.04 \mathrm{~ns}$ & 0.05 \\
\hline 30 & 9 & 34 & & 19.80 & 4.43 & 0.23 & & & 0.05 & 2.59 & $0.66 \mathrm{~ns}$ & 00 \\
\hline 37 & 13 & 50 & 31.26 & 31.65 & 7.86 & 0.41 & 25.15 & 61.79 & -0.01 & 2.18 & $1.02 \mathrm{~ns}$ & 0.00 \\
\hline 44 & 15 & 70 & 40.11 & 40.50 & 10.76 & 0.57 & 26.83 & 115.80 & -0.02 & 2.32 & $0.87 \mathrm{~ns}$ & 0.00 \\
\hline 51 & 20 & 88 & 50.42 & 51.50 & 14.88 & 0.78 & 29.50 & 221.28 & -0.05 & 2.13 & $1.22 \mathrm{~ns}$ & 0.00 \\
\hline 58 & 20 & 107 & 61.81 & 63.35 & 20.22 & 1.07 & 32.71 & 408.67 & -0.05 & 2.09 & $1.26 \mathrm{~ns}$ & 0.00 \\
\hline 65 & 21 & 127 & 74.21 & 77.35 & 24.81 & 1.31 & 33.43 & 615.45 & -0.13 & 2.04 & $1.23 \mathrm{~ns}$ & .00 \\
\hline 72 & 23 & 153 & 90.25 & 93.90 & 29.04 & 1.53 & 32.18 & 843.39 & -0.28 & 2.08 & $1.68 *$ & 0.00 \\
\hline 79 & 29 & 165 & 102.66 & 108.00 & 31.88 & 1.68 & 31.05 & 1016.04 & -0.35 & 2.13 & $1.80 *$ & 0.00 \\
\hline 86 & 41 & 190 & 121.12 & 127.00 & 34.27 & 1.81 & 28.29 & 1174.46 & -0.43 & 2.25 & $1.59^{*}$ & 0.00 \\
\hline 93 & 51 & 214 & 143.64 & 147.50 & 35.52 & 1.87 & 24.73 & 1261.84 & -0.47 & 2.40 & $1.74 *$ & 0.00 \\
\hline 100 & 58 & 221 & 155.43 & 162.00 & 36.03 & 1.90 & 23.18 & 1298.47 & -0.53 & 2.51 & $1.64 *$ & 0.00 \\
\hline 107 & 69 & 235 & 169.66 & 176.50 & 36.53 & 1.93 & 21.53 & 1334.31 & -0.54 & 2.49 & $1.75^{*}$ & 0.00 \\
\hline 114 & 74 & 268 & 182.28 & 188.00 & 37.42 & 1.97 & 20.53 & 1400.36 & -0.49 & 2.54 & $1.76^{*}$ & 0.00 \\
\hline 120 & 76 & 272 & 189.25 & 195.00 & 38.11 & 2.01 & 20.14 & 1452.03 & -0.53 & 2.60 & $1.76^{*}$ & 0.00 \\
\hline 128 & 76 & 274 & 201.11 & 206.50 & 39.47 & 2.08 & 19.63 & 1558.25 & -0.53 & 2.60 & $1.76^{*}$ & 0.00 \\
\hline 135 & 79 & 300 & 219.36 & 226.00 & 39.91 & 2.10 & 18.20 & 1593.02 & -0.58 & 2.84 & $1.41^{*}$ & 0.00 \\
\hline 141 & 85 & 304 & 225.68 & 230.50 & 39.91 & 2.10 & 17.68 & 1592.53 & -0.55 & 2.74 & $1.54 *$ & 0.00 \\
\hline 148 & 95 & 307 & 233.76 & 240.00 & 40.19 & 2.12 & 17.19 & 1615.46 & -0.53 & 2.66 & $1.66^{*}$ & 0.00 \\
\hline 156 & 125 & 317 & 240.95 & 246.50 & 40.21 & 2.12 & 16.69 & 1616.55 & -0.50 & 2.52 & $1.55^{*}$ & 0.00 \\
\hline 162 & 140 & 327 & 253.48 & 261.50 & 41.61 & 2.19 & 16.41 & 1731.10 & -0.51 & 2.53 & $1.53 *$ & 0.00 \\
\hline
\end{tabular}

(1) Days after sowing. ${ }^{(2)} *$ Significant at $5 \%$ level of probability (not normally distributed). ${ }^{\text {ns }}$ Not significant (normally distributed).

${ }^{(3)}$ p-value $\leq 0.05$, significant at $5 \%$ level of probability (series of not randomized data). 
Table 3. Minimum (min), maximum (max), mean, median, standard deviation (SD), standard error of the mean (SE), coefficient of variation (CV), variance (VAR), skewness (SK), and kurtosis (K), p-value the normality KolmogorovSmirnov test (KS) and p-value the randomness the Run Test, the stem diameter in mm, in 360 plants of pigeonpea (Cajanus cajan L.), evaluated in the seasons 2011/2012 and 2012/2013.

\begin{tabular}{|c|c|c|c|c|c|c|c|c|c|c|c|c|}
\hline $\mathrm{DAS}^{(1)}$ & $\min$ & $\max$ & mean & median & SD & SE & CV $(\%)$ & VAR & SK & $\mathrm{K}+3$ & $\mathrm{KS}^{(2)}$ & $\operatorname{Run}^{(3)}$ \\
\hline \multicolumn{13}{|c|}{ Season $2011 / 2012$} \\
\hline 62 & 5 & 14 & 8.73 & 9.00 & 1.88 & 0.10 & 21.56 & 3.54 & 0.40 & 2.82 & $2.64 *$ & 0.35 \\
\hline 69 & 5 & 17 & 10.26 & 10.00 & 2.08 & 0.11 & 20.23 & 4.31 & 0.33 & 2.78 & $2.69^{*}$ & 0.69 \\
\hline 76 & 6 & 18 & 11.53 & 11.00 & 2.29 & 0.12 & 19.85 & 5.24 & 0.32 & 2.63 & $2.51^{*}$ & 0.06 \\
\hline 83 & 7 & 21 & 12.60 & 13.00 & 2.55 & 0.13 & 20.25 & 6.51 & 0.35 & 3.03 & $1.82 *$ & 0.15 \\
\hline 90 & 8 & 24 & 14.53 & 14.00 & 3.04 & 0.16 & 20.90 & 9.22 & 0.41 & 2.94 & $1.91 *$ & 0.01 \\
\hline 98 & 8 & 25 & 15.26 & 15.00 & 3.18 & 0.17 & 20.83 & 10.10 & 0.50 & 3.17 & $1.93 *$ & 0.02 \\
\hline 104 & 8 & 27 & 15.87 & 16.00 & 3.33 & 0.18 & 20.98 & 11.09 & 0.47 & 3.08 & $1.96^{*}$ & 0.03 \\
\hline 111 & 10 & 27 & 16.51 & 16.00 & 3.54 & 0.19 & 21.45 & 12.53 & 0.38 & 2.75 & $1.83^{*}$ & 0.01 \\
\hline 119 & 10 & 28 & 16.99 & 17.00 & 3.69 & 0.19 & 21.69 & 13.58 & 0.34 & 2.64 & $1.73 *$ & 0.05 \\
\hline 125 & 10 & 30 & 17.84 & 17.00 & 4.02 & 0.21 & 22.55 & 16.18 & 0.35 & 2.72 & $1.61 *$ & 0.06 \\
\hline \multicolumn{13}{|c|}{ Season $2012 / 2013$} \\
\hline 44 & 2 & 6 & 3.84 & 4.00 & 0.95 & 0.05 & 24.74 & 0.90 & 0.08 & 2.56 & $3.72 *$ & 0.00 \\
\hline 51 & 2 & 8 & 4.89 & 5.00 & 1.20 & 0.06 & 24.43 & 1.43 & -0.12 & 2.70 & $3.42 *$ & 0.00 \\
\hline 58 & 2 & 9 & 5.48 & 5.00 & 1.38 & 0.07 & 25.21 & 1.90 & 0.07 & 2.54 & $2.70 *$ & 0.00 \\
\hline 65 & 3 & 11 & 6.03 & 6.00 & 1.63 & 0.09 & 27.07 & 2.66 & 0.33 & 2.76 & $2.57^{*}$ & 0.00 \\
\hline 72 & 3 & 12 & 7.05 & 7.00 & 1.97 & 0.10 & 27.96 & 3.89 & 0.22 & 2.54 & $2.08^{*}$ & 0.00 \\
\hline 79 & 3 & 14 & 7.69 & 8.00 & 2.16 & 0.11 & 28.09 & 4.67 & 0.31 & 2.68 & $2.09 *$ & 0.00 \\
\hline 86 & 3 & 16 & 8.28 & 8.00 & 2.41 & 0.13 & 29.13 & 5.81 & 0.29 & 2.60 & $1.96^{*}$ & 0.01 \\
\hline 93 & 4 & 17 & 9.87 & 10.00 & 2.73 & 0.14 & 27.68 & 7.47 & 0.23 & 2.57 & $2.01 *$ & 0.01 \\
\hline 100 & 4 & 19 & 10.74 & 11.00 & 2.90 & 0.15 & 26.96 & 8.39 & 0.20 & 2.69 & $1.82 *$ & 0.08 \\
\hline 107 & 4 & 22 & 11.50 & 11.00 & 3.11 & 0.16 & 27.03 & 9.66 & 0.33 & 2.85 & $1.82 *$ & 0.15 \\
\hline 114 & 4 & 22 & 12.48 & 12.00 & 3.39 & 0.18 & 27.18 & 11.51 & 0.31 & 2.72 & $1.73^{*}$ & 0.25 \\
\hline 120 & 5 & 25 & 13.34 & 13.00 & 3.55 & 0.19 & 26.61 & 12.61 & 0.40 & 2.85 & $1.68^{*}$ & 0.57 \\
\hline 128 & 5 & 26 & 14.00 & 13.00 & 3.78 & 0.20 & 26.99 & 14.28 & 0.33 & 2.77 & $2.08^{*}$ & 0.42 \\
\hline 135 & 5 & 28 & 14.64 & 14.00 & 3.96 & 0.21 & 27.05 & 15.69 & 0.35 & 2.85 & $1.64^{*}$ & 0.80 \\
\hline 141 & 5 & 31 & 15.35 & 15.00 & 4.19 & 0.22 & 27.32 & 17.59 & 0.36 & 3.04 & $1.55^{*}$ & 0.58 \\
\hline 148 & 5 & 31 & 15.89 & 16.00 & 4.40 & 0.23 & 27.68 & 19.34 & 0.33 & 2.91 & $1.67^{*}$ & 0.34 \\
\hline 156 & 6 & 33 & 16.48 & 16.00 & 4.55 & 0.24 & 27.63 & 20.73 & 0.39 & 3.14 & $1.61 *$ & 0.73 \\
\hline 162 & 6 & 34 & 17.13 & 17.00 & 4.76 & 0.25 & 27.80 & 22.69 & 0.42 & 3.12 & $1.68^{*}$ & 0.75 \\
\hline
\end{tabular}

(1) Days after sowing. ${ }^{(2)} *$ Significant at $5 \%$ level of probability (not normally distributed). ${ }^{\text {ns }}$ Not significant (normally distributed). ${ }^{(3)} \mathrm{p}$-value $\leq 0.05$, significant at $5 \%$ level of probability (series of not randomized data).

In general, the stem diameter asymmetry values were not close to 0 and kurtosis values were not close to 3 , suggesting that the data was not normally distributed (Table 3). However, based on the central limit theorem (FONSECA; MARTINS, 1995; BUSSAB; MORENTTIN, 2011), the data provides justification for the sample size used in this study, due to the large number of plants sampled (360 plants). The variability in the stem diameter $\mathrm{CV}$ values was minimal within and between seasons, demonstrating the homogeneity of observations. This CV trend was similar to that found for the height of insertion of the first pod in the cultivation of soybeans, evaluated in five experiments, with 28 
soybean genotypes (CARGNELUTTI FILHO et al., 2009).

The sample size used to estimate the mean number of nodes, with estimation error equal $4 \%$ of the mean estimate, ranged from 46 to 135 plants in the first season, and from 37 to 305 plants in the second season (Table 4). In a different study in a soybean crop, with estimation error equal $5 \%$ of the mean estimate, the sample size used to estimate the mean number of nodes ranged from 32 to 115 (CARGNELUTTI FILHO et al., 2010). Plant height sample size values used to estimate the mean displayed a similar trend compared with the number of nodes, ranging from 130 to 678 plants in the first season, to 261 to 932 plants in the second season. These results prove that greater variability is present at the beginning of the crop cycle (Table 4). The variability of the estimate of the sample size for the traits: number of nodes on the stem, plant height and stem diameter, was found in three soybean cultivars (ESTEFANEL et al., 1984). Cargnelutti Filho et al. (2010) found variability in the ideal sample size for the number of nodes in 28 soybean genotypes.

Table 4. Sample size (i.e., number of plants) required to estimate the average the number of nodes, for estimation errors equal to $2,4,6, \ldots, 20 \%$ of the mean estimate, and semiamplitude of the confidence interval (Error \%), based on 360 plants of pigeonpea (Cajanus cajan L.), evaluated in the seasons 2011/2012 and 2012/2013.

Continue ...

\begin{tabular}{|c|c|c|c|c|c|c|c|c|c|c|c|}
\hline $\mathrm{DAS}^{(1)}$ & $2 \%$ & $4 \%$ & $6 \%$ & $8 \%$ & $10 \%$ & $12 \%$ & $14 \%$ & $16 \%$ & $18 \%$ & $20 \%$ & Error \% \\
\hline \multicolumn{12}{|c|}{ Season $2011 / 2012$} \\
\hline 42 & 540 & 135 & 60 & 34 & 22 & 15 & 12 & 9 & 7 & 6 & 2.45 \\
\hline 48 & 259 & 65 & 29 & 17 & 11 & 8 & 6 & 5 & 4 & 3 & 1.70 \\
\hline 55 & 287 & 72 & 32 & 18 & 12 & 8 & 6 & 5 & 4 & 3 & 1.79 \\
\hline 62 & 266 & 67 & 30 & 17 & 11 & 8 & 6 & 5 & 4 & 3 & 1.72 \\
\hline 69 & 238 & 60 & 27 & 15 & 10 & 7 & 5 & 4 & 3 & 3 & 1.62 \\
\hline 76 & 214 & 54 & 24 & 14 & 9 & 6 & 5 & 4 & 3 & 3 & 1.54 \\
\hline 83 & 210 & 53 & 24 & 14 & 9 & 6 & 5 & 4 & 3 & 3 & 1.52 \\
\hline 90 & 195 & 49 & 22 & 13 & 8 & 6 & 4 & 4 & 3 & 2 & 1.47 \\
\hline 98 & 183 & 46 & 21 & 12 & 8 & 6 & 4 & 3 & 3 & 2 & 1.42 \\
\hline 104 & 191 & 48 & 22 & 12 & 8 & 6 & 4 & 3 & 3 & 2 & 1.45 \\
\hline 111 & 185 & 47 & 21 & 12 & 8 & 6 & 4 & 3 & 3 & 2 & 1.43 \\
\hline 119 & 188 & 47 & 21 & 12 & 8 & 6 & 4 & 3 & 3 & 2 & 1.44 \\
\hline 125 & 185 & 47 & 21 & 12 & 8 & 6 & 4 & 3 & 3 & 2 & 1.43 \\
\hline \multicolumn{12}{|c|}{ Season $2012 / 2013$} \\
\hline 16 & 1.219 & 305 & 136 & 77 & 49 & 34 & 25 & 20 & 16 & 13 & 3.68 \\
\hline 23 & 365 & 92 & 41 & 23 & 15 & 11 & 8 & 6 & 5 & 4 & 2.01 \\
\hline 30 & 353 & 89 & 40 & 23 & 15 & 10 & 8 & 6 & 5 & 4 & 1.98 \\
\hline 37 & 310 & 78 & 35 & 20 & 13 & 9 & 7 & 5 & 4 & 4 & 1.85 \\
\hline 44 & 393 & 99 & 44 & 25 & 16 & 11 & 9 & 7 & 5 & 4 & 2.09 \\
\hline 51 & 411 & 103 & 46 & 26 & 17 & 12 & 9 & 7 & 6 & 5 & 2.14 \\
\hline 58 & 464 & 116 & 52 & 29 & 19 & 13 & 10 & 8 & 6 & 5 & 2.27 \\
\hline 65 & 486 & 122 & 54 & 31 & 20 & 14 & 10 & 8 & 6 & 5 & 2.32 \\
\hline 72 & 466 & 117 & 52 & 30 & 19 & 13 & 10 & 8 & 6 & 5 & 2.27 \\
\hline 79 & 406 & 102 & 46 & 26 & 17 & 12 & 9 & 7 & 6 & 5 & 2.12 \\
\hline 86 & 355 & 89 & 40 & 23 & 15 & 10 & 8 & 6 & 5 & 4 & 1.98 \\
\hline 93 & 331 & 83 & 37 & 21 & 14 & 10 & 7 & 6 & 5 & 4 & 1.92 \\
\hline
\end{tabular}




\begin{tabular}{|c|c|c|c|c|c|c|c|c|c|c|c|}
\hline & & & & & & & & & & \multicolumn{2}{|c|}{ Continuation } \\
\hline 100 & 299 & 75 & 34 & 19 & 12 & 9 & 7 & 5 & 4 & 3 & 1.82 \\
\hline 107 & 276 & 69 & 31 & 18 & 12 & 8 & 6 & 5 & 4 & 3 & 1.75 \\
\hline 114 & 250 & 63 & 28 & 16 & 10 & 7 & 6 & 4 & 4 & 3 & 1.67 \\
\hline 120 & 212 & 53 & 24 & 14 & 9 & 6 & 5 & 4 & 3 & 3 & 1.53 \\
\hline 128 & 202 & 51 & 23 & 13 & 9 & 6 & 5 & 4 & 3 & 3 & 1.49 \\
\hline 135 & 193 & 49 & 22 & 13 & 8 & 6 & 4 & 4 & 3 & 2 & 1.46 \\
\hline 141 & 177 & 45 & 20 & 12 & 8 & 5 & 4 & 3 & 3 & 2 & 1.40 \\
\hline 148 & 168 & 42 & 19 & 11 & 7 & 5 & 4 & 3 & 3 & 2 & 1.37 \\
\hline 156 & 163 & 41 & 19 & 11 & 7 & 5 & 4 & 3 & 3 & 2 & 1.34 \\
\hline 162 & 147 & 37 & 17 & 10 & 6 & 5 & 3 & 3 & 2 & 2 & 1.28 \\
\hline
\end{tabular}

(1) Days after sowing.

Regarding the sample size for plant height, there was similarity between the two seasons when compared with the corresponding evaluation dates. During the first season, the sample size for plant height at 42 DAS, assuming a $6 \%$ error of the mean estimate, was 76 plants. In the evaluation of 360 plants, the experimental error was of $2.74 \%$. During the second season, comparing the assessment where the plant is at a corresponding growth stage, the sample size values for plant height at 44 DAS, assuming the same $6 \%$ mean error estimate, was 78 plants. This was sufficient to determine the ideal sample size for plant height, with an error $2.78 \%$, when 360 plants are measured (Table 5). In tomato cultivation it was determined that evaluations made late in the crop cycle, during two growing seasons in the laboratory and field, required a smaller sample size for the same level of precision (LÚCIO et al., 2012). The variability in the plant height sample size occurred within and between seasons. Freitas et al. (2001) observed variability in the sample size for plant height in the cultivation of upland cotton, and a difference in sample size between experiments was observed in beans (CARGNELUTTI FILHO et al., 2008) and sweet pepper (LÚCIO et al., 2003).

Table 5. Sample size (i.e., number of plants) required to estimate the average the plant height, for estimation errors equal to $2,4,6, \ldots, 20 \%$ of the mean estimate, and semiamplitude of the confidence interval (Error \%), based on 360 plants of pigeonpea (Cajanus cajan L.), evaluated in the seasons 2011/2012 and 2012/2013.

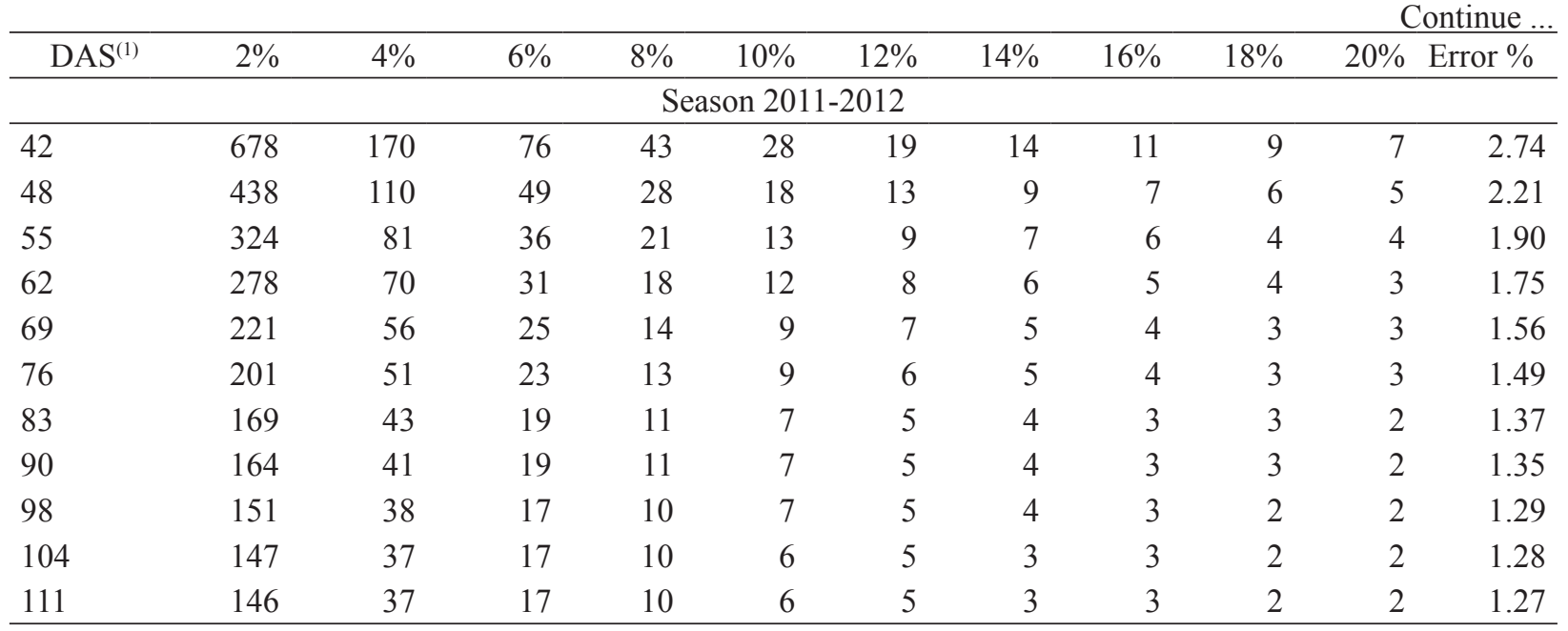




\begin{tabular}{|c|c|c|c|c|c|c|c|c|c|c|c|}
\hline & & & & & & & & & & \multicolumn{2}{|c|}{. Continuation } \\
\hline 119 & 134 & 34 & 15 & 9 & 6 & 4 & 3 & 3 & 2 & 2 & 1.22 \\
\hline 125 & 130 & 33 & 15 & 9 & 6 & 4 & 3 & 3 & 2 & 2 & 1.20 \\
\hline \multicolumn{12}{|c|}{ Season 2012-2013 } \\
\hline 16 & 932 & 233 & 104 & 59 & 38 & 26 & 20 & 15 & 12 & 10 & 3.22 \\
\hline 23 & 641 & 161 & 72 & 41 & 26 & 18 & 14 & 11 & 8 & 7 & 2.67 \\
\hline 30 & 482 & 121 & 54 & 31 & 20 & 14 & 10 & 8 & 6 & 5 & 2.31 \\
\hline 37 & 612 & 153 & 68 & 39 & 25 & 17 & 13 & 10 & 8 & 7 & 2.61 \\
\hline 44 & 696 & 174 & 78 & 44 & 28 & 20 & 15 & 11 & 9 & 7 & 2.78 \\
\hline 51 & 842 & 211 & 94 & 53 & 34 & 24 & 18 & 14 & 11 & 9 & 3.06 \\
\hline 58 & 1.035 & 259 & 115 & 65 & 42 & 29 & 22 & 17 & 13 & 11 & 3.39 \\
\hline 65 & 1.081 & 271 & 121 & 68 & 44 & 31 & 23 & 17 & 14 & 11 & 3.46 \\
\hline 72 & 1.002 & 251 & 112 & 63 & 41 & 28 & 21 & 16 & 13 & 11 & 3.34 \\
\hline 79 & 933 & 234 & 104 & 59 & 38 & 26 & 20 & 15 & 12 & 10 & 3.22 \\
\hline 86 & 775 & 194 & 87 & 49 & 31 & 22 & 16 & 13 & 10 & 8 & 2.93 \\
\hline 93 & 592 & 148 & 66 & 37 & 24 & 17 & 13 & 10 & 8 & 6 & 2.56 \\
\hline 100 & 520 & 130 & 58 & 33 & 21 & 15 & 11 & 9 & 7 & 6 & 2.40 \\
\hline 107 & 449 & 113 & 50 & 29 & 18 & 13 & 10 & 8 & 6 & 5 & 2.23 \\
\hline 114 & 408 & 102 & 46 & 26 & 17 & 12 & 9 & 7 & 6 & 5 & 2.13 \\
\hline 120 & 392 & 98 & 44 & 25 & 16 & 11 & 8 & 7 & 5 & 4 & 2.09 \\
\hline 128 & 373 & 94 & 42 & 24 & 15 & 11 & 8 & 6 & 5 & 4 & 2.03 \\
\hline 135 & 321 & 81 & 36 & 21 & 13 & 9 & 7 & 6 & 4 & 4 & 1.89 \\
\hline 141 & 303 & 76 & 34 & 19 & 13 & 9 & 7 & 5 & 4 & 4 & 1.83 \\
\hline 148 & 286 & 72 & 32 & 18 & 12 & 8 & 6 & 5 & 4 & 3 & 1.78 \\
\hline 156 & 270 & 68 & 30 & 17 & 11 & 8 & 6 & 5 & 4 & 3 & 1.73 \\
\hline 162 & 261 & 66 & 29 & 17 & 11 & 8 & 6 & 5 & 4 & 3 & 1.70 \\
\hline
\end{tabular}

(1) Days after sowing.

The sample size used to estimate the mean of stem diameter, with estimation error equal $4 \%$ of the mean estimate, ranged from 96 to 123 plants in the first season (Table 6). The sample size values for the second season were higher, ranging from 145 to 206 plants, and at the end of the crop cycle, larger sample sizes were needed to estimate the mean with the same precision and less variability, when compared to the other morphological traits evaluated (Table 6). For stem diameter, the variability of the sample size between the two seasons required higher values during the second season. Therefore, larger errors were expected in the second season. Variability in stem diameter was observed between trays with 96 Eucalyptus saligna seedlings in a nursery (ZANON et al., 1997). 
Table 6. Sample size (i.e., number of plants) required to estimate the average the stem diameter, for estimation errors equal to $2,4,6, \ldots, 20 \%$ of the mean estimate, and semiamplitude of the confidence interval (Error \%), based on 360 plants of pigeonpea (Cajanus cajan L.), evaluated in the seasons 2011/2012 and 2012/2013.

\begin{tabular}{|c|c|c|c|c|c|c|c|c|c|c|c|}
\hline $\operatorname{DAS}^{(1)}$ & $2 \%$ & $4 \%$ & $6 \%$ & $8 \%$ & $10 \%$ & $12 \%$ & $14 \%$ & $16 \%$ & $18 \%$ & $20 \%$ & Error \% \\
\hline \multicolumn{12}{|c|}{ Season 2011-2012 } \\
\hline 62 & 450 & 113 & 50 & 29 & 18 & 13 & 10 & 8 & 6 & 5 & 2.23 \\
\hline 69 & 396 & 99 & 44 & 25 & 16 & 11 & 9 & 7 & 5 & 4 & 2.10 \\
\hline 76 & 382 & 96 & 43 & 24 & 16 & 11 & 8 & 6 & 5 & 4 & 2.06 \\
\hline 83 & 397 & 100 & 45 & 25 & 16 & 12 & 9 & 7 & 5 & 4 & 2.10 \\
\hline 90 & 423 & 106 & 47 & 27 & 17 & 12 & 9 & 7 & 6 & 5 & 2.17 \\
\hline 98 & 420 & 105 & 47 & 27 & 17 & 12 & 9 & 7 & 6 & 5 & 2.16 \\
\hline 104 & 426 & 107 & 48 & 27 & 18 & 12 & 9 & 7 & 6 & 5 & 2.17 \\
\hline 111 & 445 & 112 & 50 & 28 & 18 & 13 & 10 & 7 & 6 & 5 & 2.22 \\
\hline 119 & 455 & 114 & 51 & 29 & 19 & 13 & 10 & 8 & 6 & 5 & 2.25 \\
\hline 125 & 492 & 123 & 55 & 31 & 20 & 14 & 11 & 8 & 7 & 5 & 2.34 \\
\hline \multicolumn{12}{|c|}{ Season 2012-2013 } \\
\hline 44 & 592 & 148 & 66 & 37 & 24 & 17 & 13 & 10 & 8 & 6 & 2.56 \\
\hline 51 & 578 & 145 & 65 & 37 & 24 & 17 & 12 & 10 & 8 & 6 & 2.53 \\
\hline 58 & 615 & 154 & 69 & 39 & 25 & 18 & 13 & 10 & 8 & 7 & 2.61 \\
\hline 65 & 709 & 178 & 79 & 45 & 29 & 20 & 15 & 12 & 9 & 8 & 2.81 \\
\hline 72 & 756 & 189 & 84 & 48 & 31 & 21 & 16 & 12 & 10 & 8 & 2.90 \\
\hline 79 & 764 & 191 & 85 & 48 & 31 & 22 & 16 & 12 & 10 & 8 & 2.91 \\
\hline 86 & 821 & 206 & 92 & 52 & 33 & 23 & 17 & 13 & 11 & 9 & 3.02 \\
\hline 93 & 741 & 186 & 83 & 47 & 30 & 21 & 16 & 12 & 10 & 8 & 2.87 \\
\hline 100 & 703 & 176 & 79 & 44 & 29 & 20 & 15 & 11 & 9 & 8 & 2.79 \\
\hline 107 & 707 & 177 & 79 & 45 & 29 & 20 & 15 & 12 & 9 & 8 & 2.80 \\
\hline 114 & 715 & 179 & 80 & 45 & 29 & 20 & 15 & 12 & 9 & 8 & 2.82 \\
\hline 120 & 685 & 172 & 77 & 43 & 28 & 20 & 14 & 11 & 9 & 7 & 2.76 \\
\hline 128 & 705 & 177 & 79 & 45 & 29 & 20 & 15 & 12 & 9 & 8 & 2.80 \\
\hline 135 & 708 & 177 & 79 & 45 & 29 & 20 & 15 & 12 & 9 & 8 & 2.80 \\
\hline 141 & 722 & 181 & 81 & 46 & 29 & 21 & 15 & 12 & 9 & 8 & 2.83 \\
\hline 148 & 741 & 186 & 83 & 47 & 30 & 21 & 16 & 12 & 10 & 8 & 2.87 \\
\hline 156 & 739 & 185 & 83 & 47 & 30 & 21 & 16 & 12 & 10 & 8 & 2.86 \\
\hline 162 & 748 & 187 & 84 & 47 & 30 & 21 & 16 & 12 & 10 & 8 & 2.88 \\
\hline
\end{tabular}

(1) Days after sowing.

The variability of sample size in the cultivation of pigeonpea was identified between the developmental phases of the crop (i.e., different times in the same crop year) for morphological traits. For the number of nodes and plant height, when assessed at the beginning of the crop cycle, larger sample sizes were needed due to increased variability in the observations. In a turnip culture, the sample size for productive traits was greater than that of morphological traits (CARGNELUTTI FILHO et al., 2014). Stem diameter presents low sample size variability, as it has greater homogeneity of observations throughout the crop cycle. The variability of the sample size is exemplified by corncob traits (MARTIN et al., 2005; STORCK et al., 2007), and in sorghum crop traits related to the morphology of the plant (e.g., plant height, dry matter of shoots, panicle length 
and dry matter of panicle) (SILVA et al., 2005).

\section{Conclusion}

There was variability in the ideal sample size in a pigeonpea culture depending on the morphological traits evaluated, evaluation period and season. To assess with $6 \%$ precision of the mean estimate, at least 136 plants must be evaluated throughout the pigeonpea crop cycle to determine the ideal sample size to accurately measure the following traits: number of nodes, plant height and stem diameter, at different evaluation periods and between seasons.

\section{Acknowledgements}

We thank the Brazilian National Council for Scientific and Technological Development (CNPq) and the Coordination for the Improvement of Higher Level Personnel (CAPES), for granting scholarships and the Rio Grande do Sul Research Foundation (FAPERGS) for financial support.

\section{References}

BARBETTA, P. A.; REIS, M. M.; BORNIA, A. C. Estatística para cursos de engenharia e informática. São Paulo: Atlas, 2004. 410 p.

BUSSAB, W. O.; MORETTIN, P. A. Estatística básica. 7. ed. São Paulo: Saraiva, 2011. 540 p.

CAMPOS, H. Estatística e experimentação agronômica: amostragem I. Piracicaba: ESALQ/USP, 1985. 17 p.

CAMPOS, H. Estatística experimental não-paramétrica. 4. ed. Piracicaba: Escola Superior de Agricultura Luiz de Queiroz da Universidade de São Paulo, 1983. 349 p.

CARGNELUTTI FILHO, A.; EVANGELISTA, D. H. R.; GONÇALVES, E. C. P.; STORCK, L. Tamanho de amostra de caracteres de genótipos de soja. Ciência Rural, Santa Maria, v. 39, n. 4, p. 983-991, 2009.

CARGNELUTTI FILHO, A.; FACCO, G.; LÚCIO, A. D.; TOEBE, M.; BURIN, C.; FICK, A. L.; NEU, I. M. M. Tamanho de amostra para a estimação da média de caracteres morfológicos e produtivos de nabo forrageiro. Ciência Rural, Santa Maria, v. 44, n. 2, p. 223-227, 2014.
CARGNELUTTI FILHO, A.; LOPES, S. J.; BRUM, B.; SILVEIRA, T. R.; TOEBE, M.; STORCK, L. Tamanho de amostra de caracteres em híbridos de mamoneira. Ciência Rural, Santa Maria, v. 40, n. 2, p. 250-257, 2010.

CARGNELUTTI FILHO, A.; LOPES, S. J.; TOEBE, M.; SILVEIRA, T. R.; SCHWANTES, I. A. Tamanho de amostra para estimação do coeficiente de correlação de Pearson entre caracteres de Crambe abyssinica. Revista Ciência Agronômica, Fortaleza, v. 42, n. 1, p. 149-158, 2011.

CARGNELUTTI FILHO, A.; RIBEIRO, N. D.; STORCK, L.; JOST, E.; POERSCH, N. L. Tamanho de amostra de caracteres de cultivares de feijão. Ciência Rural, Santa Maria, v. 38, n. 3, p. 635-642, 2008.

ESTEFANEL, V.; SACCOL, A. V.; SCHNEIDER, F. M. Tamanho da amostra para estimar características agronômicas da soja. Revista do Centro de Ciências Rurais, Santa Maria, v. 14, n. 3-4, p. 221-229, 1984.

FARIAS, L. N.; SILVA, E. M. B.; SOUZA, W. P.; VILARINHO, M. K. C.; SILVA, T. J. A.; GUIMARÃES, S. L. Características morfológicas e produtivas de feijão guandu anão cultivado em solo compactado. Revista Brasileira de Engenharia Agrícola e Ambiental, Campina Grande, v. 17, n. 5, p. 497-503, 2013.

FONSECA, J. S.; MARTINS, G. A. Curso de estatistica. 5. ed. São Paulo: Atlas, 1995. 317 p.

FREITAS, J. A.; SILVA, E. B.; FALLIERI, M. A. L.; FARIA, R. S.; SILVA, P. J. Tamanho de amostra na parcela para caracterização da altura de plantas de algodoeiro herbáceo Gossypium hirsutum. Ciência Rural, Santa Maria, v. 31, n. 4, p. 583-587, 2001.

LÚCIO, A. D.; HAESBAERT, F. M.; SANTOS, D.; SCHWERTNER, D. V.; BRUNES, R. R. Tamanhos de amostra e de parcela para variáveis de crescimento e produtivas de tomateiro. Horticultura Brasileira, Botucatu, v. 30, n. 4, p. 660-668, 2012.

LÚCIO, A. D.; SOUZA, M. F.; HELDWEIN, A. B.; LIEBERKNECHT, D.; CARPES, R. H.; CARVALHO, M. P. Tamanho da amostra e método de amostragem para avaliação de características do pimentão em estufa plástica. Horticultura Brasileira, Botucatu, v. 21, n. 2, p. 180-184, 2003.

MAIOR JÚNIOR, S. G. S.; SOUTO, J. S.; SANTOS, R. V.; SOUTO, P. C. Produção de fitomassa do feijão guandu em diferentes arranjos populacionais. Tecnologia e Ciência Agropecuária, João Pessoa, v. 3, n. 1, p. 1-5, 2009. 
MARTIN, T. N.; STORCK, L.; LUCIO, A. D.; LORENTZ, L. H. Plano amostral em parcelas de milho para avaliação de atributos de espigas. Ciência Rural, Santa Maria, v. 35, n. 6, p. 1257-1262, 2005.

NENE, Y. L.; SHEILA, V. K. Pigeonpea: geography and importance. Estadística no paramétrica aplicada a las ciencias de la conducta. México: Trillas, 1990. 346 p.

SILVA, P. S. L.; BARBOSA, Z.; GONCALVES, R. J. S.; SILVA, P. I. B.; NUNES, G. H. S. Sample size for the estimation of some sorghum traits. Revista Brasileira de Milho e Sorgo, Sete Lagoas, v. 4, n. 2, p. 149-160, 2005.

SPIEGEL, R. A.; SCHILLER, J.; SRINIVASAN, R. A. Probabilidade e estatística. 2. ed. Porto Alegre: Bookman, 2004. 398 p.

STEEL, R. G. D.; TORRIE, J. H.; DICKEY, D. A. Principles and procedures of statistics. A biometrical approach. 3. ed. New York: McGraw Hill Co, 1997. 666 p.
STORCK, L.; LOPES, S. J.; CARGNELUTTI FILHO, A.; MARTINI, L. F. D.; CARVALHO, M. P. Sample size for single, double and three-way hybrid corn ear traits. Scientia Agricola, Piracicaba, v. 64, n. 1, p. 30-35, 2007.

STRECK, E. V.; KÄMPF, N.; DALMOLIN, R. S. D.; KLAMT, E.; NASCIMENTO, P. C.; SCHNEIDER, P.; GIASSON, E.; PINTO, L. F. S. Solos do Rio Grande do Sul. 2. ed. Porto Alegre: Emater/RS, 2008. 222 p.

VAN DER MAESEN, L. J. G. Origin, history and taxonomy of pigeonpea. Oxford: $\mathrm{CAB} /$ International Crops Research Institute for the Semi Arid Tropics, 1990. $46 \mathrm{p}$.

WUTKE, E. B. Forragens na seca: algaroba, guandu e palma forrageira. Campinas: Fundação Cargil, 1986. v. $1,137 \mathrm{p}$.

ZANON, M. L. Z.; STORCK, L.; FINGER, C. A. G.; HOPPE, J. M. Sample size for experiments of Eucaliptus Saligna smith in the tree nursery. Ciência Florestal, Santa Maria, v. 7, n. 1, p. 133-138, 1997. 